\title{
Systemic Defects in the EMU and Small Countries in Central and Eastern Europe
}

\author{
Yoji Koyama*
}

\begin{abstract}
The euro, which was created in 1999, facilitated regional foreign trade in the euro, but combined with financial liberalization and global financialization it brought a massive cross-border capital flow and major banks' operating without control, leading to real estate bubbles in the periphery in Southern Europe and New EU member states in the mid-2000s. When the Lehman shock occurred in September 2008 the capital inflow in these countries suddenly stopped and reversed. In order to rescue the banking sector which had a huge amount of non- performing loans governments' were obliged to inject fresh capital into banks, resulting in an expansion of government debt. In order to decrease governments' debt the Troika (European Commission, European Central Bank and the IMF) imposed austerity measures on the EU periphery countries as a prerequisite for financial support, but this policy in turn has caused economic stagnation in these countries. This paper considers the systemic defects in the EMU and policy problems in the Eurozone.
\end{abstract}

Keywords: banking sector, problem of the Eurozone, European Union, Economic and Monetary Union

\section{Introduction}

European integration, which originated from the desire not to repeat a war in Europe, has developed from the joint management of steel and coal to the European Economic Community (EEC), the European Community (EC) and the European Union (EU). This is a grandiose political project. The integration has developed not only in space but also in depth. In the 1980 s, however, the EC was in stagnation because companies in the EU were overwhelmed by export offensives from US and Japanese companies. The EC aimed to enhance the competitiveness of European companies by the creation of a single EC-wide market. The Single European Act, which entered into effect in July 1987, aimed to complete an internal market not only for financial services but also for goods, labour and capital by 1992. Thanks to the single license system for banks, which came into operation in 1989, a bank license issued by authorities in a member state became valid in other member states. The report by the Committee on the Economic and Monetary Union (Delors Committee) was published in April 1989 and was approved by the European Council in June in the same year. The establishment of the Economic and Monetary Union (EMU) was incorporated in the Maastricht Treaty,

\footnotetext{
*Yoji Koyama, PhD., Professor Emeritus at Niigata University, Japan, e-mail: ZAC00343@nifty.com.
} 
which was signed in February 1992 and entered effect in November 1993. Meanwhile, capital mobility on the financial market within the EC was completely liberalized in July 1990.

In order to create a common currency and keep confidence in it, the economic convergence of prospective member states of the EMU was necessary. The extent of their economic convergence came to be measured mainly in fiscal and financial aspects. The explicit convergence criteria, which prospective member states of the EMU should satisfy, are included in the Maastricht Treaty. The following are the criteria: (1) Price stability; (2) Budget (budget deficit less than $3 \%$ of GDP); (3) National public debt (cumulative national debt less than $60 \%$ of GDP); (4) Long-term interest rate; (5) Currency fluctuation. In addition, these criteria have been reinforced by the Stability and Growth Pact (1997) which was concluded at Germany's strong request. This sets the limit of budget deficit within 3\% of GDP even after the adoption of the euro.

It appeared that the EU economy had been developing smoothly after the inception of the euro, but after experiencing the 2008 global financial crisis and the subsequent Eurozone crisis, the EU economy's stagnation stands out. There are many pessimistic opinions about the future of the Eurozone'. It seems that there are problems in the systemic design of the EMU and the underlying idea. Many people discuss this point from various angles. For example, 1) When the Greek crisis surfaced in 2010 the EU could not decide on their financial support due to the "non-bailout clause" of the Treaty of the EU functioning ${ }^{2}$. 2) The Eurozone is not an optimal currency area ${ }^{3}$. On this point Soko Tanaka (2015: 226) said the following: "Originally the role of the theory of an optimal currency area is to compare the cost and benefit before the formation of a unified currency area and judge the scope of the 'optimal area"'. In the case of the Eurozone, even if it was formed beyond the optimal currency area,

${ }^{1}$ There are various opinions about the future of the Eurozone. Many pessimistic views are expressed. Among them, Brendan Brown (2012) points out that in addition to vital flaws in the design of the EMU the ECB made mistakes in its judgments of the situations and policy-makings for 10 years and proposes the establishment of a new monetary union (EMU-2). Two British economists, Baimbridge and Whyman (2015) point out problems of the EMU and propose that monetary sovereignty is returned to each member state and that a European version of the international clearing union, which John Maynard Keynes proposed at the end of World War II, is established. Martin Wolf (2014: 292) likens problems of the euro crisis to an "unhappy marriage". According to him, the possible outcomes are (1) divorce; (2) continuation of a bad marriage; or (3) the creation of a good marriage. Today the member states are dangling between the first two alternatives. The marriage is pretty bad, but divorce looks frighteningly painful. He proposes to turn this into a good marriage. At present this proposal seems to be the most practical.

${ }^{2}$ However, the credit insecurity has calmed down for the time being by bold policies and a speech "the ECB will do anything to protect the euro" by Mario Draghi who took the post of the ECB Governor in November 2011.

${ }^{3}$ Since intra-regional labor mobility has been insufficient and redistribution among member states through the budget has also been insufficient (although there has been transfer through the EU' structural funds and cohesion fund, the amount has been small), the Eurozone is not an optimal currency area (OCA). Unlike the USA, the Eurozone started as a monetary union without a fiscal union. The endogeneity hypothesis of the OCA theory emphasizes the positive relationship between monetary integration and economic convergence. According to this somewhat optimistic view, once a country enters a common-currency area, even if it did not satisfy the criteria ex ante, eventually through economic integration such as improvements in intra-union trading relationships, the country can satisfy the criteria ex post. In contrast, however, the specialization hypothesis of the OCA theory argues that trade integration will enhance the specialization of each country's production since countries will tend to export more of those goods where they possess a comparative advantage (Baimbridge and Whyman, 2015: 64-65). It will take more time to be able to judge which is correct, but for the time being the specialization hypothesis seems the more convincing. 
it would be no use saying now that this is not an 'optimal currency area' as the Eurozone member states have decided to maintain the unified currency area. Also I think that the problem of the political will is the most important and, as will be described later, if governments and people in the Eurozone agree to take a step forward toward fiscal federalism then the Eurozone would approach an optimal currency area further.

In this paper I do not want to discuss about 1) and 2) any more. Rather I want to discuss the systemic defects in the EMU which allowed major banks to go out of control since the inception of the euro. The euro, which was created in 1999, facilitated foreign trade within the EU and combined with financial liberalization and global financialization in the 1990s, caused massive cross-border capital flow and banks' reckless behaviour. This has brought real estate bubbles in the EU member states in the middle of the first decade of the 21st century. When the Lehman shock occurred in October 2008 and the inflow of capitals stopped suddenly and then the direction of the capital flows are reversed. In order to rescue the banking sector, which had a huge amount of non-performing loans, the governments were obliged to inject fresh capitals into banks out of their budgets resulting from the expansion of governments' debt. In order to decrease governments' debt the Troika (European Commission, European Central Bank and IMF) imposed austerity on EU periphery countries as a prerequisite for financial support, but this policy in turn has caused economic stagnation in these countries. So far, problems of the EU, for example, the crisis in the Eurozone, etc., have been usually discussed taking into consideration core member states (EU 15). Such problems have seldom been discussed from the viewpoint of New EU member states (NMS) from Central and Eastern Europe (CEE). I would like to add the viewpoint of NMS, small countries in particular, to the analysis of the problems of the Eurozone crisis.

This paper is structured as follows: Section 1 points out the systemic defects in the EMU and discusses problems of financial integration which has encouraged cross-border capital flow on an optimistic premise; Section 2 analyses the Eurozone crisis from a viewpoint of NMS from CEE. Taking the cases of small countries in the CEE, this section examines the impacts on their economies of cross-border capital inflow, its sudden stop and the reversal of its flow after the Lehman shock; Section 3 presents policy problems in the Eurozone, especially austerity and argues that a policy change will be inevitable; Section 4 examines the direction of reforms in the EU; and Section 5 puts forward some conclusions.

\section{Establishment of the EMU}

The establishment of the EMU was affected by the political judgment of politicians at that time. There was a widespread concern that as Germany's power in the EC would rise with the fall of the Berlin Wall and the collapse of socialism in Eastern Europe in 1989 and the unification of Germany in 1990 this country might drift eastward. The European Central Bank (ECB), the central bank for the Eurozone as a whole, has been located in Frankfurt am Main in Germany. It is said that the French President at that time Mitterrand approved 
this location to compensate for Germany's renunciation of the Deutsche Mark ${ }^{4}$. The system and character of the ECB became similar to those of Germany's Bundesbank. However, this point was already determined by Delors' Committee already before the fall of the Berlin Wall in November 1989. Konoe (2014: 213) and De Grauwe (2011: 211-216) explain the circumstances. This committee was formed by the European Council in 1988 and submitted its report in April 1989. Governors of the central banks in the EC member states participated in this committee in private capacities and the "monetarist paradigm" was dominant among them. In addition, Germany was the most successful in the control of inflation. In this way, having inherited the character of the Bundesbank, the character of the ECB is somewhat different from that of the central banks in other countries. In the Anglo-French model, for example, the central bank pursues several purposes, i.e., price stability, business cycle stability, maintenance of employment at a high level, financial stability, etc. Price stability is only one of its purposes. This type is characterized by the subordination of the central bank to politics. In the German model price stability is the primary objective of the central bank. "Maintenance of employment at a high level" is only secondary. It is characterized by its political independence (De Grauwe 2011: 222-227). The economic thought at its foundation has been Ordo economics which has been quite critical toward Keynesian economics. According to Blyth (2013: 113), Ordo economists put an emphasis on the role of the state. They see "the role of the state as setting the framework conditions necessary for markets to operate effectively in the first instance". They dislike "the macroeconomic manager focused on the demand side of the economy that emerged out of British New Liberalism. Rather the ordoliberal state is a rule setter that enables competition and aids market adjustments through the development of specific economy-wide mechanism and institutions". This standpoint is consistent with that of the German government in the Eurozone crisis. The economics that European economists and the EU technocrats who designed the EMU believe in are neoclassical economics or Monetarism (Hoshino 2015: 24), which is affinitive with Ordoeconomics.

Major European banks were involved in the global financial crisis. They "developed financial businesses no more or no less risky than American investment banks", and the former and the latter were "principal culprits and accomplices in the global financial crisis" (Hoshino 2015: 75) respectively. Major European banks were deeply involved in the subsequent credit uncertainty in the Eurozone too, but such serious events were not supposed at the time of the establishment of the EMU. According to Hoshino (2015: 215), the original purposes of the EMU were as follows: "Firstly, the euro was supposed to bring prosperity and stability in Europe and furthermore political integration, which was the ultimate goal of European integration, through the supplementation of regional integration, promotion of fundamental structural reforms and encouragement of strengthening solidarity among member states". Secondly, "by becoming an international currency competitive against US dollars, the euro was supposed to contribute to prosperity and stability in the world economy

\footnotetext{
${ }^{4}$ Soko Tanaka (2016): 52.
} 
through putting an end to the financial domination by the USA and the construction of a symmetric and stable international currency system". The world view that the EMU depicted is in pre-established harmony due to the idea on which it is based. Hyman Minsky (1919-96) was in the minority in the field of economics while he was alive but he came to attract attention after the global financial crisis. He thought, "Our economy has an innate and irreversible defect, and the defect occasionally causes financial instability" (Minsky 1989: 15). The European Commission and the ECB did not have such a perception ${ }^{5}$.

At the time of the establishment of the EMU (the first stage from July 1990 and the second stage from January 1994) there were no unified regulative and supervisory institutions for banking, securities and insurance at the EC/EU level but these institutions were dispersed. When the EU started to function in January 1994 it adopted a new approach "minimum harmony" and "regulation and supervision by a home country + mutual recognition". Unlike "the harmonized approach" before 1985, this was "a decentralized approach in which the way of the protection of investors and depositors was unified only at a necessary minimum level and then a home country's corresponding institutions would regulate and supervise activities of their financial institutions abroad and a host country would approve them" (Iwata 2003: 221). In his paper of 2003, although having felt the necessity for the "creation of new supervisory authorities at a European level", in conclusion David Mayes (2003: 209) stated that: "it would be wise in terms of timing to start such a reform at the present moment when the European banking system is stable. As experiences in Nordic countries show, however, the history suggests that changes could be caused only when we experienced a crisis". In fact, in 2008 and in 2010-2011 the world witnessed serious crises. With hindsight, it was proved that the EMU, which was included in the Maastricht Treaty (1992) and entered the third stage of its development by the creation the euro, did not fit the trend of financial liberalization and global financialization at all ${ }^{6}$.

Financial integration brought a cross-border capital flow on a pan-European scale including emerging markets in Central and Eastern Europe. Not only in the Eurozone but also in NMS which were admitted to the EU in 2004 interest rates have decreased. From the mid-1990s through the early 2000s most of the banks in Central and Eastern Europe were acquired by major Western European bank groups, which in turn gave loans actively to households and enterprises causing bubbles there. Not only that, major European banks

\footnotetext{
${ }^{5}$ There is a view, which, marks a new era and explains the causes of the global financial crisis by using the concept of "financialisation". According to Radosevic and Cvijanic (2015: 9), "financialisation" denotes "the increasing role of financial motives, financial markets, financial actors and financial institutions in the operation of the domestic and international economies". They explain "financialisation" in a shortened way as follows: "the predominance of finance over real sector of an economy" (Radosevic, Cvijanic 2015: 13). Financialisation started around 1980, and the fundamental cause of the 2007/8 global financial crisis and the subsequent Eurozone crisis should be viewed in the context of financialisation. It seems that this is an important viewpoint in consideration of the global financial crisis and the Eurozone crisis. Also Hoshino (2015: 54) grasps these problems from this viewpoint.

${ }^{6}$ Soko Tanaka (2016) mentions the restriction by the times. In his opinion, the euro regime was constructed in 1989-1991. The systems design was done taking into account the financial situations and international financial situations for about 30 years from 1960 to the 1980s which was the period of overwhelmingly stabilized finance in the total history of capitalism.
} 
have been deeply involved in subprime mortgages in the USA. The yields of sovereign debts in the periphery in Southern Europe including Greece have decreased. All of them were regarded as safe assets. Still, albeit slightly, they had higher yields than sovereign debts in northern European countries including Germany. Blyth (2013: 81) says the following: "If you swapped out your low-yield German and Dutch debt and replaced it with as much as PIIGS debt as you could find, and then turbocharged that by running operating leverage ratio as high as 40 to 1 - higher than your US counterparts - you would have one heck of institutionally guaranteed money machine". Thus European major banks have been run without control. Until recently the supervision of branches of foreign-owned banks in a host country was entrusted to a home country's supervisory authorities. "The limitations of decentralized system of supervision and control of banks based on the inter-government principle were revealed" (Hoshino 2014: 118).

\section{Situations in Small Countries in Central and Eastern Europe}

Critical situations in periphery countries in Southern Europe including Greece (Ireland is included in this case) have attracted attention, but situations in the NMS in the CEE were also serious. Here are the cases of 3 countries, Latvia (population as of 2014 is a little less than 2 million); Slovenia (a little more than 2 million) and Croatia (about 4.24 million) are discussed. Inflows of foreign capitals in these countries took the following routes: 1) inward foreign direct investment (FDI); 2) portfolio investment; and 3) other investments (funds transfer from parent banks to local branches and between banks), among which 1) and 3) are important. An analysis of the movement in inflows and outflows of capitals is represented by Latvia's case.

\subsection{Latvia}

Latvia, one of the Baltic States, has had common characteristics with Estonia and Lithuania. After gaining independence from the Soviet Union in September 1991 Latvia aimed actively at participation in the Western economy, joined the EU in 2004 and adopted the euro in January 2013 following Estonia (January 2011). The Baltic States have actively attracted foreign capitals. Foreign capitals, which had flowed into these countries since the mid-1990s, greatly contributed to their economic development bringing about 2-digit economic growth rates in the middle of the first decade of the 21st century.

The share for manufacturing has been very small. FDI inflow concentrated mainly in non-tradable sectors such as retail trade, real estate and financial services. In these countries the unemployment rate recorded a double-digit in 2001. After EU accession, unemployed persons, low-skilled workers and construction workers in Latvia migrated to EU member countries, mainly the UK and Ireland on a massive scale. The unemployment rate rapidly decreased, and the labour market became tight causing a rapid increase in nominal income. 
At the same time, Nordic banks advanced to the Baltic States. Swedish banks in particular were very active. Nordic banks' strategies toward the Baltic States were viewed by Estonian economists as the following: "The Nordic banks opted for aggressive business strategies to gain market share and set nominal interest rates and other loan conditions at levels quite similar to those in their home markets" (Hansson, Randveer 2013: 6). A Swedish economist, who viewed from the opposite side of the Baltic coast, pointed out, "Their fight for market shares fuelled an unprecedented credit expansion in the Baltic region with exploding asset prices for houses etc., but also including an extreme surge in conspicuous consumption of capital goods like luxurious cars etc., all financed by easy credits"7. However, all of the Baltic States were hit hard by the 2008 global financial crisis and recorded a 2-digit negative economic growth in 2009. Among them Latvia's case was the most serious.

In Latvia the economic growth rate was as high as $12.2 \%$ in 2006 . The inflation rate soared reflecting a consumption boom and a housing bubble. As the inflation rate was so high, from the end of February through early March 2007 the Lat, the Latvian currency, came under pressure of depreciation on foreign markets and the central bank was forced to intervene in the market for the first time in several years. The government of Latvia finally switched its policy to manage aggregate demand more actively and launched a package of measures geared to delivering a durable reduction. The restrained policies began to be effective in the autumn. Property prices started to decline and by October were around $12 \%$ lower than at the start of 2007. Thus the housing bubble burst. The Lehman shock in September 2008 dealt the Latvian economy a final blow.

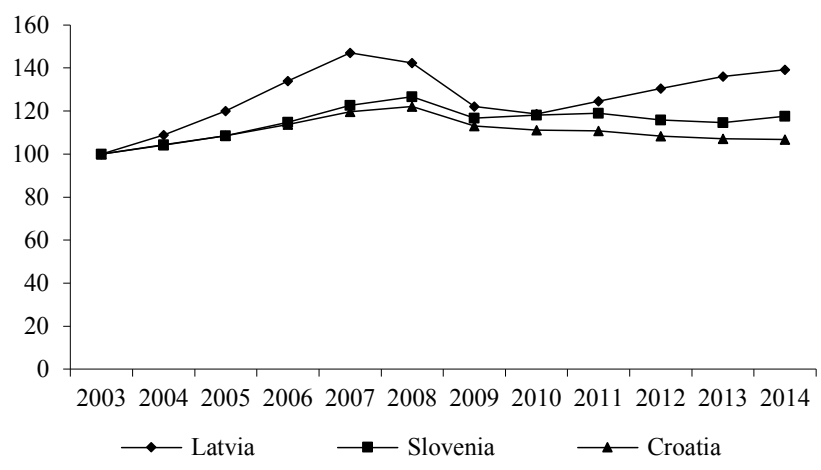

Figure 1. GDP Growth Rates in 3 Countries

Source: Prepared by the author based on data from Eurostat.

Looking at Table 1, we can find that the FDI inflow turned negative in the 4th quarter of 2008 and in the section of other investment assets-banks recorded negative values for three consecutive quarters from the 4th quarter of 2008, meaning a net outflow of capital

${ }^{7}$ An e-mail from Dr. Leif Vindevag, August 2009 
during these periods. Parex Bank, the second largest bank in Latvia, was greatly exposed to a sudden outflow of non-resident deposits (a kind of bank run) and faced serious liquidity constraints. In the top ten banks in Latvia there were four domestic banks with their total market share being $29.5 \%$. The remaining share was occupied by six subsidiaries of foreign banks, of which three were Swedish banks. In contrast to Latvia, the subsidiaries of foreign banks occupy an overwhelming majority of the total share in Estonia (98.7\%) and Lithuania (85.3\%). Thanks to this, both countries were able to find a way out of the financial crisis. In Latvia, however, Parex Bank was an indigenous bank which rapidly grew by collecting deposits from non-residents (people in Russia and the CIS) and had no parent bank behind it, and therefore could not find a way out of the financial crisis. In early November the government nationalized this bank to prevent bankruptcy.

\section{Table 1}

Inflows and outflows of capitals in Latvia: from the fourth quarter of 2007 through the second quarter of 2009

\begin{tabular}{lrlrrrrr}
\hline & \multicolumn{1}{l}{2007} & \multicolumn{2}{c}{2008} \\
\cline { 2 - 8 } & Q4 07 & Q1 08 & Q2 08 & Q3 08 & Q4 08 & Q1 09 & Q2 09 \\
\hline Current account & $-771,444$ & $-627,842$ & $-627,651$ & $-533,233$ & $-324,662$ & 42,254 & 478,811 \\
Trade balance & $-739,399$ & $-584,950$ & $-562,515$ & $-583,441$ & $-487,146$ & $-138,120$ & 1,853 \\
FDI inflow & 190,939 & 270,322 & 269,921 & 209,708 & $-143,453$ & 15,812 & $-128,980$ \\
Portfolio investment & 19,530 & 302,142 & $-163,085$ & 19,723 & 19,398 & 43,532 & 48,170 \\
\hline Other investment & & & & & & \\
Assets-banks & $-853,090$ & 638,142 & $-356,208$ & 342,011 & $-86,743$ & 492,653 & $-215,311$ \\
Liabilities-banks & $1,148,314$ & $-304,627$ & 899,064 & 240,324 & $-575,445$ & $-1,293,496$ & $-501,244$ \\
\hline
\end{tabular}

Source: Bank of Latvia, Quarterly Bulletin Latvia's Balance of Payments, iss. of 4Q 2008 and 3Q 2009.

Without resorting to a devaluation of the Lat, the country responded to this crisis by its people's desperate efforts to improve its export competitiveness by internal depreciation (through the reduction of wages, pensions and public services). Latvia has often been mentioned as a successful example of a country which has accomplished a V-shape recovery after the crisis (see Figure 1), but we should not forget the tremendous sacrifice such as the exodus of about $10 \%$ of the population to foreign countries since the start of the global financial crisis. The public debt as a percentage of GDP in 2014 was 40.7\%, which was not serious, but the external debt exceeding $140 \%$ GDP was a cause for concern.

\subsection{Slovenia}

Having inherited the tradition of self-management socialism from former Yugoslavia, this country is characterized by neo-corporatism (cooperative relationship among government, managers' association and trade unions' associations), quite different from other post-socialist countries. Its transition to a market economy was carried out in a gradualist way and 
privatization was implemented with priority being given to insiders. This country has had a relatively high level of technology and strong international competitiveness. Most Slovenians have been rather cautious about the sale of their productive assets to foreigners. Other countries in the CEE have been willing to invite FDI in order to supplement insufficient domestic capitals and absorb advanced technology and managerial know-how. In contrast, Slovenia has not been so enthusiastic in attracting FDI. Rather this country has been more enthusiastic in outward FDI since the early days. With the exception of 2002 and 2004, the amount of outward FDI exceeded that of inward FDI until 2007. When the country was admitted to the EU in May 2004 it had already satisfied the Maastricht convergence criteria and after having joined the ERM II in June in the same year the country was admitted to the EMU, i.e., adoption of the euro in January 2007 earlier than any other NMS. In that sense this country was the best performer among the NMS. I would like to add that until the middle of the first decade of the 21 st century the country's current account had been almost balanced, the budgetary deficit had been small and both public debt and external debt had been relatively small (Table 2 ).

Table 2

Changes in Public debt and External debt in 3 Countries

\begin{tabular}{llrrrrrrrr}
\hline Year & & 2004 & 2008 & 2009 & 2010 & 2011 & 2012 & 2013 & 2014 \\
\hline Latvia & Public debt & 14.9 & 19.8 & 36.7 & 44.5 & 42.8 & 41.3 & 39.8 & 40.7 \\
& External debt & 92.7 & 130.0 & 157.1 & 166.2 & 147.0 & 137.6 & 133.7 & 141.6 \\
\hline \multirow{2}{*}{ Slovenia } & Public debt & 27.2 & 22.0 & 35.0 & 38.6 & 46.9 & 53.7 & 70.8 & 80.8 \\
& External debt & 56.7 & 105.3 & 113.3 & 114.4 & 111.2 & 119.1 & 116.0 & 124.2 \\
\hline Croatia & Public debt & 37.8 & 29.3 & 35.8 & 42.2 & 63.7 & 69.2 & 80.8 & 85.1 \\
& External debt & 71.6 & 83.6 & 97.7 & 103.6 & 103.7 & 103.0 & 105.6 & 108.4 \\
\hline
\end{tabular}

Notes: Public debt by definition of the EU; External debt is in gross value.

Source: Current Analyses and Forecasts, with, various issues.

In this country, however, the euro adoption combined with neoliberal courses taken by the centre-right coalition government caused a sudden increase in the inflows of foreign capital, and a bubble economy. In the case of this country, its dependency on inward FDI was relatively small. Rather banks' borrowing on international financial wholesale markets played an important role. Slovenian banks borrowed short-term capitals at low interest rates and then provided domestic companies with loans in large quantities. This small country with an open economy was hit hard by the reversal of international capital flow after the 2008 global financial crisis. Although the economy picked up somewhat in 2010-2011, it fell into serious depression in 2012 under a "double-dip" recession in the Eurozone. Since then the Slovenian economy recorded negative economic growth for three consecutive years. A larger proportion of loans provided to the construction sector and financial holding companies became non-performing. It was three major banks under state control that 
actively gave loans to these companies. These banks suffered from a huge amount of nonperforming loans.

The government embarked on rescuing the banking sector. Transferring most of the nonperforming loans to a newly-established "bad bank", the government injected fresh capitals into these banks. Due to this, the country's budgetary deficit finally amounted to a staggering $14.4 \%$ of GDP in 2013. Thus the public debt increased rapidly from $22 \%$ of GDP in 2008 to $80.8 \%$ in 2014. At the same time the gross external debt also increased rapidly from 56.7 $\%$ of GDP in 2004 to $105.3 \%$ in 2008 and to $124.2 \%$ in 2014 (Table 2). In order to decrease the public debt the country has been obliged to take austerity measures. In addition, the Troika is pressing the government to promote privatization in the area of infrastructure and make the labour market more flexible

\subsection{Croatia}

Domestic banks were acquired by foreign banks one after another from the end of 1998 through to 2003. Such a change was a part of drastic change of a pan-European scale in the banking industry in which in parallel with the creation and circulation of euro West European major banking groups advanced to the emerging market of the CEE. Foreign-owned banks were able to provide households and firms in Croatia with cheaper loans. At the same time, foreign currency deposits also become widespread. Therefore, the Croatian economy is called a euro-ized economy.

The central bank could not control foreign-owned commercial banks sufficiently. In 2004, for example, the central bank tried to regulate the inflow of foreign capitals by imposing a special tax on borrowing in foreign currencies, but the commercial banks redirected loans to Croatian companies to direct loans from their parent banks in order to circumvent such measures by the central bank. Initially banks' loans were predominantly given to the corporate sector, but over time the Croatian banking sector has gradually moved toward more emphasis on retail loans (financing consumption and import). From corporate lending (financing production and exports in the manufacturing sector), commercial banks moved to lending to retail (financing consumption and imports). Much of the external flows went into consumption and non-tradable sectors (construction, real estate, and wholesale and retail trade), feeding into higher imports. In this way, the Croatian economy became very vulnerable to external shocks. When the global financial crisis occurred in 2008 the cross-border inflow of funds suddenly stopped and the direction of the flow was reversed causing a negative economic growth in 2009. Officially the exchange rate has been the managed floating, but de facto and has been pegged to the Euro. The range of its fluctuation has been very narrow ( $\pm 5 \%$ of central parity) and much narrower than the case of the ERM II $( \pm 15 \%)$. The Kuna has been appreciated. Nevertheless, hoping to adopt the euro early, the Croatian monetary authorities have been diligently maintaining the exchange rate without 
devaluing the Kuna. Since mid-2009 the government and the central bank have pursued a strategy of internal devaluation, but it has proved to be ineffective.

\subsection{Lessons from the Three Countries' Experiences}

The small countries in the CEE were at the mercy of massive cross-border capital inflow, which caused bubbles in the middle of the first decade of the 21st century, which suddenly stopped when the Lehman shock occurred in 2008 and then reversed. Due to a decrease in the budget revenue, an increase in social expenditures and the governments' support of domestic banks, the budget deficit expanded. Especially in the case of Slovenia where domestic banks had a larger share, the government became heavily burdened. Slovenia was less dependent on foreign capital and pursued more independent development, but it is now obliged to change its development strategies and is pressed for privatization not only from major banks but also from state-owned companies in the infrastructure by the European Commission and IMF.

Latvia is a beneficiary country of the "Vienna Initiative", which was agreed by EUbased private financial institutions and pubic financial institutions in Vienna in January 2009. Other beneficiary countries include Hungary, Romania, Serbia, and Bosnia and Herzegovina. It is said that West European major banks, which gave loans to these countries, agreed not to withdraw funds massively from them and that the initiative has been very effective. However, we should be mindful of the fact that it has a content that the initiative committed Western European banks to keeping their funds in their Eastern European banks if these governments committed austerity measures to stabilize local banks' balance sheets (Blyth 2013: 221). We should pay attention to the fact that austerity was imposed as conditionality on these countries only several months after the Lehman shock ${ }^{8}$.

Although Croatia has not joined the Eurozone yet, hoping an early euro adoption it has been maintaining the Kuna's euro-peg with the Kuna being appreciated. Consequently, austerity has brought 'debt deflation' in this country too. Its economy recorded negative growth for a consecutive 6 years from 2009 through 2014 (see Figure 1). This was the longest depression among the post-socialist countries in the CEE.

The above-mentioned facts tell us the following two points: firstly, there should be some regulation on cross-border capital flow, at least on short-term cross-border capital flow. Secondly, instead of the principle of home country supervision, Eurozone-wide financial supervisory institutions should be created. Thirdly, austerity can no longer be maintained in the EU member states, and consequently their policy changes are inevitable.

${ }^{8}$ Blyth (2013: 216), mentions the cases of the Baltic States (Estonia, Latvia and Lithuania), which aimed at economic development relying on foreign capital. Beginning in 2008 they voluntarily embraced an extraordinarily deep fiscal adjustment, keeping their currencies pegged to the euro while internal prices and wages collapsed. In 2009 Romania and Bulgaria joined these three countries. Although officially there is not such an expression, He named these countries the "REBLL Alliance". The Troika praise these 5 countries as successful examples of "expansionary austerity, but it is doubtful when we take into account the amount of sacrifice that these countries paid (2013: 216-226). 


\section{Austerity}

Leaders of the Eurozone often met and discussed serious problems of public debt in Southern Europe including Greece, but its supportive measures were taken little by little too late and as a consequence aggravated the crisis. When the Greek crisis surfaced they misunderstood the nature of the crisis and mistakenly responded to the crisis. Crises in other countries were "liquidity" crises, i.e., a problem of temporary cash shortage; therefore, if the payment of their debts is postponed by bridging loans then the crises would be solved in time whereas the case of Greece was an "insolvency" crisis. Greece needed a prompt reduction of its debt (Takemori 2015: 137-138). If the debt was had been reduced much earlier the situation would not have become so serious.

Germany is the most influential member state in the Eurozone. Leaders of the Eurozone, German Chancellor Angela Merkel in particular, emphasized budgetary discipline and requested Greece to take rigorous austerity measures as a condition for support through the EFSF (European Financial Stabilization Facility). Giving priority to a decrease in the budget deficit, Germany requested Greece to implement economic reforms including a reduction in the number of public employees and a cut in the existing pension system, etc. These merciless austerity measures have deprived the Greek economy of any remaining energy for activating the economy, causing a vicious circle of a decline in aggregate demand, a decline in the level of economic activity, an increase in the unemployment rate and again an expansion of the budget deficit. In Greece, the unemployment rate increased to $25 \%$ with $50 \%$ being of the total being young people thus intensifying social unrest.

The "Sovereign debt crisis" has been widely publicized, but budget deficit is not a real problem. Prior to the 2008 global financial crisis it was only Greece that had an excessive budget deficit. In the case of other Southern European countries and Ireland, the fiscal conditions were not so dire. Their fiscal stance worsened only after the bubble burst due to the global financial crisis. The euro crisis was a "banking crisis" (Soko Tanaka 2016: 43). We must be careful with the logic which replaces problems of banks' failure with problems of governments' debt and austerity. It is Blyth (2013) that sharply criticizes this point. The essentials of his argument are as follows:

Politicians today in both Europe and the United States have succeeded in casting government spending as reckless wastefulness that has made the economy worse. In contrast, they have advanced a policy of draconian budget cuts - austerity - to solve the financial crisis. We are told that we have all lived beyond our means and now need to tighten our belts. This view conveniently forgets where all that debt came from. Not from an orgy of government spending, but as the direct result of bailing out, recapitalizing, and adding liquidity to the broken banking system. Through these actions private debt was rechristened as government debt while those responsible for generating it walked away scot free, placing the blame on the state, and the burden on the taxpayer (Blyth 2013, book cover). 
The logic which was used for bailing out the banks was "too big to fail" in the USA and "collectively too big to fail" in Europe. In order to protect the banking system governments in the EU member states recapitalized more or less, thus increasing governments' debt. Most of the advanced countries more or less adopted Keynesian active fiscal policies in order to escape from the depression after the Lehman shock, but as early as in June 2010 the G20 summit held in Toronto decided on a changeover from a powerful stimulative policy to austerity. According to Blyth (2015: 61), "The final communiqué of the Toronto meeting repeated the meme authored by Trichet and amplified by Schauble, of 'growth friendly fiscal consolidation'. At that time the most decisive influence on European policy-makers was given an argument of "an expansionary fiscal consolidation" raised by Alberto Alesina, an Italian economist of the Bocconi school ${ }^{9}$ (Blyth 2013: 169-176). In this way, the Troika imposed austerity on periphery countries as a prerequisite for support on the ground that austerity would cause growth.

From a critical standpoint a young Italian economist Paternesi Meloni (2015) explains the mistakes in austerity as follows: The European Commission recommended deficit countries to implement structural reforms on the grounds that current account differentials were almost exclusively referred to their weak competitiveness. He explains the logic underlying austerity measures which have been imposed on peripheral countries: Firstly, in order to restore government debt sustainability - the reducing of the debt-to-GDP ratio, mitigating market losses of trust and the lowering of risk premiums (expansionary austerity); secondly, in order to restore external competitiveness through internal devaluation - real wage reduction and structural reforms (competitive austerity). This is the neoliberal view placing an emphasis on the supply side. As a matter of fact, an improvement in the current account occurred not through these channels, but through a channel of a decrease in aggregate demand, leading to a decrease in total output, and a decrease in consumption and a decrease in imports. In this way, this policy has brought debt deflation. Paternesi Meloni disproves the austerity - competitiveness linkage and, based on Keynesian economics, argues the necessity of putting an emphasis on the demand side.

In spite of its obvious collapse in practice, the European Commission and the ECB still stick to austerity, imposing it on peripheral countries in the Eurozone. If not only a single country but also multiple countries in the Eurozone implement austerity together it would lead to a decrease in their total demand by a "paradox of economy", causing what Keynes calls "an error of combination" internationally. Austerity does not work well. A subtle difference in the unity of the Troika came to surface. On July 2, 2015 when the IMF published its provisional report of the Debt sustainability Analysis (IMF, 2015), saying that in order to make Greece's debt sustainable a substantial reduction in the debt and an extension of

\footnotetext{
${ }_{9}^{9}$ According to Blyth (pp. 165-166), Luigi Einaudi (1874-1961), the founder of a school of public finance economics at the Bocconi, produced an economics, which is the last link in the fossil record of economic ideas that explain why we came to think, once again, that we call and cut our way to growth at the same time. He sought the development of a "liberalism economy" through savings and competition and rejected Keynesian state intervention.
} 
its repayment period would be necessary ${ }^{10}$. At the time of the East Asian financial crisis in 1997-1998, the IMF responded arrogantly to countries which fell into crisis. It is ironical that the IMF proposes debt reduction for Greece, showing a more flexible attitude than the European Commission and the German government.

\section{Direction of Reforms in the EU}

\subsection{Creation of the Banking Union}

It can be viewed as one step forward that a reform in the supervision of banks is being made in the direction of a formation of unified supervision at the Eurozone level instead of the principle of home country supervision. The banking union is being created. Ultimately this should consist of a) Single Banking Supervisory Mechanism (SSM), b) Single Resolution Mechanism (SRM), and c) Common Deposit Insurance Mechanism (CDIM), with authority over their operation being put at the Eurozone level (Soko Tanaka 2016: 100). As for SSM, out of about 6,000 banks in the Eurozone the ECB specified about 200 major banks, which possess about $85 \%$ of the total assets of all banks, as "important banks" and control them directly. Remaining small and medium-sized banks shall be supervised by supervisory institutions in member states with the unified responsibility being born by the ECB. The SSSM and the SRM have started, but the CDIM was removed from the present reform due to objections raised by some member states including Germany. Its creation remains as a future challenge.

\subsection{EDP and MIP}

Important measures taken recently to prevent a recurrence of a serious crisis are the "Excessive Deficit Procedure" (EDP) and "Macroeconomic Imbalance Procedure" (MIP). The former is to be implemented for the EU member states which violated the obligation of Stabilization and Growth Pact (budget deficit less than 3\% of GDP), and if the correction is not made soon the penalty is inflicted in which $50 \%$ to $100 \%$ of funds transferred from the EU budget is suspended. In addition to EDP, MIP was introduced in 2010. EU member states are to be checked every year about whether or not they exceed reference values in 5 items on external imbalances and competitiveness (current account balance as \% of GDP, net international investment position as \% of GDP, changes in a real effective exchange rate, changes in export market shares, and changes in nominal unit labour cost) and 6 items on internal imbalances (changes in house prices, private sector credit flow as \% of GDP, private sector debt as \% of GDP, government debt as \% of GDP, unemployment rate, and changes

\footnotetext{
${ }^{10}$ Takemori (2015: 40-43) says there are differences in the approach to the problem of Greek debt among the Troika. Also Blyth (2015: 363-365) expresses a similar opinion. In his long postscript (written in August 2014) of the Japanese edition (published in September 2015) he writes that in recent years the IMF came to have conflicting relations with the European Commission and the ECB.
} 
in total financial sector liabilities). For member states which exceed the reference values in several items, in-depth reports are to be prepared. For especially serious member states MIP is to be implemented, and the countries concerned are to be requested to take corrective measures. In 2013 MIP was implemented for Spain and Slovenia. If the violation (exceeding reference values) is not corrected, then a penalty of up to $0.5 \%$ of GDP is to be inflicted on the country concerned. However, there are concerns that a country, which is in an economic predicament, may diminish growth and worsen the deficit by a suspension of EU transfers or a penalty (Richter 2013: 53-54).

\subsection{European Semester}

In 2011 the European Semester was introduced in order to monitor the operations of economic policies in EU member states every six months. Prior to official decisions of the draft budget and economic policies in member states, the European Commission is empowered to examine them by this system (JETRO 2011). The above-mentioned EDP and MIP are used as measures for reinforced fiscal monitoring and measures for the maintenance of cooperation especially for the Eurozone member states. Every time violations are made a penalty is inflicted. Therefore, this is as it were "a union of numerical targets and penalties" (Hiroshi Tanaka 2015). The Eurozone member states are, as it were, dressed in "straitjackets", and their economies look like "planned economies". It is yet to be seen whether such a direction will be correct or not. In this way, the rules which support the euro are increasingly becoming complicated. Blyth (2015: 92) says, "Imagine the future as a space of unrealized possibilities. You can accept that uncertainty and roll with it, or you can try to make the future behave within certain specified parameters, narrowing the space of possible futures. The way you do is with rules. So long as they are clearly stated and everyone follows them, then according to this logic, the future will unfold, as you would like to see it, in accordance with the rules. This is ordoliberalism gone mad, as well as the logic behind the euro" and points out "epistemic hubris" (p. 91).

\subsection{Remaining Challenges}

Grexit was narrowly avoided for the time being, but a possibility of the Grexit in the future cannot be completely excluded. Even if Greece withdraws from the Eurozone, the problems inherent in the Eurozone would remain. There is also a possibility that another member state from Southern Europe facing a serious crisis might be obliged to withdraw. As the Eurozone has structural problems it is deemed urgent that fundamental reforms be implemented. There remains disparity in international competitiveness between northern Europe including Germany and the peripheral countries. This is a structural problem which cannot be simply treated as a lack of effort. The latter countries cannot use a method of devaluation of the exchange rate in the framework of the present EMU. Consequently, expectations for 
fiscal federalism are increasing. If the EU takes a step forward toward fiscal federalism, where the European Commission has a more solid fiscal foundation and distributes funds among member states, it would imply great progress, but this seems to be quite difficult under the present circumstances.

However, Soko Tanaka (2016: 234-235) discusses a scenario for overcoming the problem of core and periphery after having presented the theory of "cumulative causal relationship" which a Swedish economist Gunar Myrdal advocated. Tanaka says, "As for the system of fiscal transfer in a monetary union, in fact, in the 1970s its study had been made as an essential system in the concept of monetary union" (Soko Tanaka 2016: 234), mentioning "Maljoran Report" (1975) and "Report of the McDougal Committee" (1977). According to him, at that time when there existed only 9 member states, it was considered that if a monetary union was created peripheral member states would lose the power of devaluation of the exchange rates and therefore a public system of funds transfer as its compensation would be necessary. In the 20th century it was considered that if only a few member states get a huge amount of benefit from the economic and monetary union and other member states get the short end of the stick then integration would not advance. Leaders at that time had the principle of "equal distribution of benefit from the integration" in their mind. At present, however, "Germany, which has gained a huge amount of benefit from the integration and the euro depreciation, has forgotten the spirit and tries to make self-defence on the ground of the already collapsed 'non bailout' clause"' (Soko Tanaka 2016: 236). Tanaka's idea is very suggestive.

\section{Conclusion}

The global financial crisis, the subsequent credit insecurity in the Eurozone and its economic stagnation indicate that the system of the EMU and the Eurozone countries' economic policies have serious problems: firstly, a cross-border capital flow is useful for countries with a shortage of capital, but a rapid and massive capital inflow and its rapid outflow is harmful to these countries. As for a cross-border capital flow there should be some regulation, and at least short-term capital flow should be regulated; secondly, in order to improve the system which allowed major banks' to run without control systemic reforms are underway, and this is a step forward. However, the present reform has its limitations; thirdly, austerity has already collapsed. As the economies of peripheral countries, which were imposed austerity by the Troika, have been stagnating it would be inevitable for them to change the policy; fourthly, it will be indispensable to develop the system of fiscal transfer at the EU

${ }^{11}$ This theory can be summarized as follows: "As enterprises, technology, information, finance, etc. are being accumulated in the core the region can continue to enjoy its advantages. It becomes increasingly richer by absorbing workers and capitals from periphery while due to the loss of labor power and capitals for the economic activation, combined with poor infrastructure such as communication, transport, education, etc., periphery is moving from stagnation to decline. As the rich core becomes increasingly richer the gap between the core and poor periphery widens in a cumulative way" (Soko Tanaka, 2016: 229-230). For Myrdal's theory of cumulative causal relationship, see Fujita (2003). 
level, otherwise it would be very difficult for non-euro NMS to adopt the euro ${ }^{12}$. When the EU makes a step forward toward this direction, the movement should be decided by political dynamics in various fields including the European Parliament where politicians act reflecting voices from periphery in Southern Europe and the NMS.

\section{References}

Baimbridge \& Whyman (2015), Crisis in the Eurozone: Causes, Dilemmas and Solutions, Palgrave MacMillan.

Brown B. (2012), The Euro's Collapse, The Japanese edition (translated by Katsumasa Tamura) was published by Ittosha in 2012.

Blyth M. (2013), Austerity: the History of a Dangerous Idea, Oxford University Press. The Japanese edition (translated by Masazumi Wakatabe and Katsuyoshi Tamura) was published by NTT Shuppan in 2015.

De Grauwe P. (2009), Economics of Monetary Union, The Japanese edition (2011) (translated by Soko Tanaka and Masaki Yamaguchi) was published Keiso Shobo.

Fujita N. (2003), Theory of Cumulative Causal Relationship in Myrdal, "Keizai Kagaku” vol. 51, no. 2 (in Japanese). Hansson, Randveer (2013), Economic Adjustment in the Baltic Countries, Easti Pank, Working Paper Series, 1/2013. Hoshino K. (2015), EU Keizai Tsuka Tohgoh to Euro Kiki, Tokyo: Nihon Hyoronsha.

IMF (2015), Greece: Preliminary Draft Debt Sustainability Analysis, Country Report no. 15/165. https://www.imf. org/external/pubs/cat/longres.aspx?sk=43044.0 (accessed on January 16, 2016).

Iwata K. (ed.) (2003), Euro to EU no Kin'yu System, Tokyo: Nihon Hyoronsha.

Iwata K. (2003), EU no Shohken Kisei no Shin Tenkai, Chapter 8 of Iwata (ed.) (2003).

JETRO (2011), Yorropa Semester no Gaiyo to Kongo no Sukejuru, "Yuro Torendo" no. 4.

Konoe S. (2014), EMU no Kesei to Kin'yu Anteika: Bundan sareta Seisaku Katei to Kongo no Yukue, EU Studies in Japan, no. 34.

Koyama Y. (2015a), The EU's Eastward Enlargement: Central and Eastern Europe's Strategies for Development, Singapore: World Scientific.

Koyama Y. (2015b), EU Accession and the Collapse of Casino Capitalism in Small Countries in Central and Eastern Europe: Focus on Latvia and Slovenia, in Global Financial Crisis: Causes, Consequences and Impact on Economic Growth, ed. J. Barnett, NY: Nova Science.

Koyama Y. (ed.) (2016), The Eurozone Enlargement: Prospect of New EU Member States for the Euro Adoption, NY: Nova Science.

Martin W. (2014), The Shifts and the Shocks: What We've Learned - and Have Still to Learn - from the Financial Crisis, The Japanese edition (translated by Masami Endo) was published by Hayakawa Shobo in 2015.

Mayes D.G. (2003), EU niokeru Ginkoh Kantoku no Shin Tenkai, Chapter 7 of Iwata (ed.).

Minsky H. (1986), Stabilizing an Unstable Economy, The Japanese edition (translated by Osamu Yoshino, Toichiro Asada and Kazuo Uchida) was published by Taga Shuppan.

Paternesi M.W. (2015), Austerity and competitiveness: a misleading linkage, Paper presented at the 1st World Congress of Comparative Economic Studies, held at Rome Tre University on June 25-27.

Radosevic, Cvijanovic (eds.) (2015), Financialisation and Financial Crisis in South-Eastern European Countries, Fankfurt am Main: Peter Lang GmbH.

Richter S. (2013), Macroeconomic Conditionality: a Threat to Cohesion Policy Transfers from 2014 onwards?, Gligorov, Vladimir, et al., Animal Spirits still Dimmed: Slow Recovery Expected, Current Analyses and Forecasts 12, wiiw.

Takemori S. (2015), Ohshu Tohgoh Girisha ni Shisu. Tokyo: Kohdansha.

Tanaka H. (2015), Euro to EU Keizai wa Dokoni Mukau noka, "Keizai", September iss. of 2015.

Tanaka S. (2015), Euro Kiki to Seido Kaikaku: Euro 2.0 heno Hatten, Seiichi, Nakajo and Yoshimasa Komoriya, eds.

Tanaka S. (2015), Euro Kiki to Grisha no Hanran, Tokyo: Iwanami.

\footnotetext{
${ }^{12}$ For the prospect of NMS from CEE for euro adoption, see Koyama (2016).
} 


\section{OGÓLNOUSTROJOWE WADY UNII GOSPODARCZO-WALUTOWEJ KRAJÓW EUROPY ŚRODKOWEJ I WSCHODNIEJ}

Streszczenie: Waluta euro, która od roku 1999 funkcjonuje w transakcjach bezgotówkowych, ułatwiła regionalny handel zagraniczny w strefie euro, ale w połączeniu z liberalizacją finansową oraz globalną finansyzacją przyniosła ogromne transgraniczne przepływy kapitału i brak kontroli nad działalnością dużych banków, co prowadzi do baniek na rynku nieruchomości na obrzeżach Europy południowej i krajów nowej Unii w połowie 2000 roku. Po szoku związanym z upadkiem banku Lehman Brothers, który wystąpił we wrześniu 2008 roku, napływ kapitału w tych krajach nagle zatrzymał się i odwrócił. W celu ratowania sektora bankowego, który posiadał wiele zagrożonych kredytów, rządy były zmuszone do zasilenia banków „świeżym” kapitałem, powodując wzrost długu publicznego. W celu zmniejszenia zadłużenia rządów Trojka (Komisja Europejska, Europejski Bank Centralny i MFW), jako warunek pomocy finansowej, zmusiła peryferyjne kraje UE do przyjęcia planów oszczędnościowych, ale ta polityka spowodowała z kolei stagnację gospodarczą w tych krajach. Artykuł ten przedstawia wady systemowe w UGW i polityczne problemy w strefie euro.

Słowa kluczowe: sektor bankowy, problem strefy euro, Unia Europejska, Unia Gospodarczo-Walutowa

\section{Citation}

Koyama Y. (2016). Systemic Defects in the EMU and Small Countries in Central and Eastern Europe. Finanse, Rynki Finansowe, Ubezpieczenia, 1 (79), 687-704; www.wneiz.pl/frfu. 